\title{
Pengaruh Eksistensi Hutan Mangrove terhadap Aspek Sosial, Ekonomi dan Kearifan Lokal Masyarakat Pesisir di Desa Jaring Halus, Kecamatan Secanggang, Kabupaten Langkat
}

\author{
Adnin Musadri Asbi ${ }^{1}$, Rahman Abdel Rouf ${ }^{2}$ \\ ${ }^{1}$ Program Studi Perencanaan Wilayah dan Kota, Jurusan Teknologi Infrastruktur dan Kewilayahan, \\ Institut Teknologi Sumatera, Jalan Terusan Ryacudu, Way Hui, Kecamatan Jati Agung, Lampung Selatan 35365 \\ ${ }^{2}$ Alumni Program Studi Kehutanan, Fakultas Kehutanan, Universitas Sumatera Utara, \\ Jalan Tri Dharma Ujung No. 1 Kampus USU, Medan 20155 \\ Correspondence email: adnin.asbi@pwk.itera.ac.id
}

\begin{abstract}
Abstrak. Menyadari akan pentingnya kebutuhan hidup yang berasal dari sumberdaya alam, diperlukan suatu jalan keluar guna memadukan aspek ekologi dan ekonomi agar dapat berjalan secara seimbang. Penelitian ini secara khusus meneliti perspektif masyarakat Desa Jaring Halus dalam hubungannya dengan keberadaan ekosistem hutan mangrove dengan metode observasi. Dalam penelitian ini juga dianalisis hubungan eksistensi mangrove dengan aspek sosial, ekonomi dan kearifan lokal masyarakat setempat serta mencari solusi untuk meningkatkan taraf pendapatan masyarakat dengan menggunakan data hasil kuesioner yang dianalisis secara deskriptif kuantitatif. Hasil studi menunjukkan bahwa sebesar $92.85 \%$ masyarakat merasakan dampak positif dari terpeliharanya hutan mangro ve. Masyarakat Desa Jaring Halus memiliki kearifan lokal yang tidak tertulis dalam mengelola dan menjaga kelestarian hutan mangrove untuk mempertahankan keutuhan sosial dan ekonomi yang berkesinambungan. Dalam rangka peningkatan taraf pendapatan masyarakat, diperlukan pembuatan tempat pembibitan mangrove secara permanen yang dikelola oleh pemerintah desa dan dikerjakan oleh masyarakat serta dipasarkan keluar desa untuk meningkatkan penghasilan rumah tangga dengan memanfaatkan rencana pencetusan Desa Jaring Halus sebagai KEE (Kawasan Ekosistem Ekowisata).
\end{abstract}

Kata kunci: hutan mangrove; kearifan lokal; masyarakat pesisir

\begin{abstract}
Recognizing the importance of living needs derived from natural resources, a solution is needed to integrate ecological and economic aspects in order to work in balance. This research specifically examines the perspective of the people of Desa Jaring Halus in relation to the existence of mangrove forest ecosystem based on observation method. This study also analyzed the relationship of mangrove existence with social, economy and local wisdom of local community as well as looking for solution to increase income level of society by using questionnaire. The data derived from the questionnaire were analyzed descriptively quantitative. The results show that $92.85 \%$ of people feel the positive impact of maintained mangrove forest. The people of Jaring Halus Village have an unwritten local wisdom in managing and preserving mangrove forests to maintain social and economic sustainability. In order to increase the income level of the community, it is necessary to make a permanent mangrove nursery which is managed by the government performed by the community and marketed out of the village according to its allocation to increase household income by utilizing the development of Jaring Halus Village as Ecosystem Ecotourism Area.
\end{abstract}

Keywords: coastal communities; local wisdom; mangrove forest

\section{PENDAHULUAN}

Indonesia memiliki hutan mangrove terluas di dunia, yakni mencakup $21 \%$ dari luas total dunia. Di Indonesia, mangrove tersebar hampir di seluruh pulaupulau besar mulai dari Sumatera, Jawa, Kalimantan, Sulawesi hingga ke Papua, dengan luas yang sangat bervariasi bergantung pada kondisi fisik, komposisi substrat, kondisi hidrologi, dan iklim yang terdapat di pulau-pulau tersebut (Spalding dkk, 2010).

Hutan mangrove sangat menunjang perekonomian masyarakat pesisir, karena merupakan sumber mata pencaharian masyarakat pesisir yang mayoritas berprofesi sebagai nelayan. Secara ekologis hutan mangrove dapat berfungsi sebagai habitat biota laut, penyangga perlindungan wilayah pesisir, pelindung dari berbagai ancaman sedimentasi, abrasi, intrusi air laut, serta merupakan tempat pemijahan bagi ikan yang hidup di laut bebas (FAO, 1992).

Hutan mangrove sering disebut juga sebagai hutan pasang surut, hutan payau atau hutan bakau. Istilah bakau sebenarnya merupakan nama dari salah satu jenis tumbuhan mangrove yaitu Rhizophora spp. (Nybakken, 1992; Bengen, 1998). Hutan ini merupakan tipe hutan tropika yang khas tumbuh di sepanjang pantai atau muara sungai yang dipengaruhi oleh pasang surut air laut. Mangrove banyak ditemukan di pantai atau muara sungai yang dipengaruhi oleh pasang surut air laut (Anwar dan Subiandono, 1996; Vanucci, 2001). Di Indonesia tercatat setidaknya 202 jenis tumbuhan di hutan mangrove, meliputi: 89 jenis pohon, 5 jenis palma, 19 jenis pemanjat, 44 jenis herba tanah, 44 jenis epifit, dan 1 jenis paku (Noor, 1999).

Hutan mangrove merupakan salah satu sumberdaya alam tropika yang memiliki fungsi dan manfaat yang luas ditinjau dari aspek ekologisekonomi. Fungsi ekologis mangrove dapat dilihat dari aspek fisik, kimia, dan biologi (Bengen, 1998; Vanucci, 2001). Menurut Khazali (2001), fungsi ekonomi hutan mangrove berkaitan dengan pemanfaatan produk produk hutan mangrove yang dapat diperjualbelikan baik kayu (kayu bakar, bahan bangunan, arang, pulp, dan tanin) maupun non kayu (obat-obatan dan ikan), pemanfaatan untuk rekreasi (wisata alam) dan pendidikan. Beberapa faktor utama penyebab kerusakan mangrove yaitu: pencemaran, konversi hutan mangrove yang kurang memperhatikan faktor lingkungan, dan penebangan yang berlebihan (Kusmana, 1999; Khoja, 2000; Alho, 2002; Effendi, 2004), dan menurut Babo 
dan Froehlich (1998), kerusakan hutan mangrove karena dikonversi menjadi tambak. Menyadari akan pentingnya kebutuhan hidup yang berasal dari sumberdaya alam, diperlukan suatu jalan keluar guna memadukan aspek ekologis dan ekonomis supaya dapat berjalan bersama-sama dan seimbang. Prinsip ini merupakan prinsip prinsip kearifan lokal yang dihormati dan dipraktekkan oleh beberapa komunitas masyarakat (Noor et al, 1999).

Desa Jaring Halus dipilih sebagai lokasi penelitian berdasarkan informasi awal dari Balai Besar Konservasi Sumber Daya Alam (BBKSDA) Sumatera Utara bahwa masyarakat di Desa Jaring Halus yang berbatasan langsung dengan Suaka Margasatwa Langkat Timur Laut (SM LTL) dilibatkan dalam pengelolaan Suaka Margasatwa tersebut, dimana tutupan lahan SM LTL didominasi oleh hutan mangrove. Salah satu dasar pelibatan masyarakat Desa Jaring Halus adalah kearifan lokal yang dimiliki masyarakat dalam mengelola hutan mangrove desanya. Aspek sosial ekonomi pengelolaan hutan mangrove oleh masyarakat Desa Jaring Halus merupakan salah satu bentuk kearifan lokal yang digunakan untuk mengelola ekosistem mangrove (BBKSDA, 2006).

Untuk itu penulis menilai bahwa perlu dilakukan studi persepsi masyarakat pesisir yang hidup berbatasan dengan hutan mangrove untuk mengetahui seberapa besar pengaruh langsung dari keberadaan hutan mangrove terhadap pertumbuhan ekonomi, aspek sosial pengelolaan hutan mangrove, serta solusi untuk meningkatkan pendapatan masyarakat, terutama masyarakat Desa Jaring Halus dengan memanfaatkan hutan mangrove secara lestari.

\section{METODE PENELITIAN \\ Tempat dan Waktu Penelitian}

Penelitian ini dilaksanakan di Desa Jaring Halus, Kecamatan Secanggang, Kabupaten Langkat, Sumatera Utara. Adapun yang menjadi daerah titik fokus kegiatan penelitian ini adalah seluruh wilayah Desa Jaring Halus mulai dari dusun I sampai dusun V. Waktu yang dibutuhkan untuk melaksanakan penelitian ini adalah 3 bulan (Oktober - Desember 2016).

\section{Alat dan Bahan Penelitian}

Alat yang digunakan dalam penelitian ini adalah kamera dan alat tulis. Sedangkan bahan yang digunakan dalam penelitian ini adalah perangkat kuisioner, serta dokumen lain yang berhubungan dengan lokasi dan kegiatan penelitian. Data kuisioner yang digunakan dapat dilihat pada Tabel 1.

Tabel 1. Kuisioner yang digunakan dalam penelitian

No. Nama Jenis Kelamin Umur Pekerjaan Utama Pekerjaan Sampingan Pendapatan per bulan

\section{Populasi dan Sampel}

Populasi yang menjadi objek penelitian yaitu seluruh masyarakat yang bertempat tinggal atau telah lama menetap (setidaknya satu tahun menetap) di Desa Jaring Halus. Berdasarkan data terbaru dari Kantor Desa Jaring Halus, penduduk Desa Jaring Halus berjumlah sebanyak 3.294 jiwa dan terbagi atas 769 kepala keluarga (KK). Metode penentuan sampel sebagai responden yang digunakan pada populasi masyarakat yang tinggal di Desa Jaring Halus mengacu pada Arikunto (2006), yang menyatakan bahwa jika jumlah subjek masyarakat yang ingin diwawancari kurang dari 100 orang maka perlu diambil kesemuanya sebagai penelitian populasi, selanjutnya apabila jumlah populasinya lebih dari 100 orang maka diambil 10-15\% atau $20-25 \%$ atau lebih tergantung pertimbangan peneliti. Maka sampel yang diambil dalam penelitian ini adalah sebanyak $10 \%$ dari jumlah total kepala keluarga (KK) Desa Jaring Halus yaitu sebanyak 70 sampel warga sebagai objek penelitian. Kegiatan survei dilakukan dengan pengamatan lapangan dan melakukan wawancara terhadap beberapa key person yakni tokoh masyarakat, wakil kepala desa, ketua ikatan petani dan nelayan Jaring Halus (IPANJAR), dan 70 orang masyarakat/nelayan.

\section{Pengumpulan dan Analisis Data}

Setiap responden diwawancara berdasarkan kuisioner yang telah dipersiapkan. Bahan pertanyaan di dalam kuisioner meliputi data diri, kehidupan sosial ekonomi masyarakat, pengetahuan masyarakat terhadap mangrove dan pengelolaan mangrove oleh masyarakat. Penelitian ini bersifat deskriptif dengan variabel penelitian yang terdiri dari kerusakan hutan mangrove dan dampak terhadap ekonomi masyarakat nelayan tradisional. Untuk mendapatkan data yang diperlukan dalam penelitian ini, digunakan teknik pengumpulan data berupa wawancara (Interview) dan observasi (Rating Scale).

\section{Indikator Keluarga Sejahtera}

Menurut Badan Pusat Statistik (2005), ada delapan indikator penting untuk mengetahui tingkat kesejahteraan, yaitu pendapatan, konsumsi atau pengeluaran keluarga, keadaan tempat tinggal, fasilitas tempat tinggal, kesehatan anggota keluarga, kemudahan mendapatkan pelayanan kesehatan, kemudahan mendapatkan fasilitas pendidikan, dan fasilitas transportasi.

\section{HASIL DAN PEMBAHASAN Deskripsi Lokasi}

Desa Jaring Halus merupakan desa dengan jumlah masyarakat sebesar 3.294 jiwa yang terdiri dari laki-laki sebanyak 1.668 jiwa dan perempuan sebanyak 1626 jiwa dengan jumlah KK sebanyak 769 jiwa. Berdasarkan letak astronomisnya, Desa Jaring Halus berada pada posisi 03051'30" $\neg$ 03059'45" LU dan 98030'-98042' BT. Terletak pada daerah pantai dengan ketinggian 1 meter di atas permukaan laut dengan luas desa 17,5 hektar.

Berdasarkan datakomposisi penduduk mayoritas adalah suku Melayu 90\% sebagai suku asli Desa Jaring Halus dan selebihnya adalah suku lain yang berstatus 
sebagai pendatang dan menetap di Desa Jaring Halus dengan bahasa mayoritas yang digunakan adalah bahasa melayu. Menurut mata pencaharian penduduknya, yang berprofesi sebagai nelayan/buruh nelayan adalah yang paling tinggi yaitu sebesar $90 \%$ dan selebihnya adalah pedagang, Pegawai Negeri Sipil (PNS) dan lain-lain. Adapun batas-batas Administrasi Desa Jaring Halus adalah sebagai berikut:

- Sebelah Utara berbatasan dengan Selat Malaka.

- Sebelah Timur berbatasan dengan Desa Selotong.

- Sebelah Selatan berbatas dengan Desa Secanggang.

- Sebalah Barat berbatasan dengan Desa Tapak Kuda.

\section{Karakteristik Responden Penelitian Umur}

Umur responden yang diteliti ber-dasarkan pertimbangan bahwa responden memiliki pengetahuan mengenai lingkungan sekitar berdasarkan usia, yakni terkait dengan pengalaman hidupnya dengan lingkungan sekitar di mana responden melakukan interaksi langsung maupun tidak langsung dengan lingkungan sekitarnya. Umur responden dikategorikan ke dalam lima kelas umur. Mulai dari umur 20 tahun sebagai umur responden termuda yang dianggap cukup kompeten dalam mengetahui lingkungannya dan dapat mengkomunikasikan perspektifnya, hingga umur 70 tahun yang diperkirakan mewakili usia tertua yang dapat diwawancarai. Berikut dapat dilihat pada Tabel 2.

Tabel 2.Distribusi responden berdasarkan kelas umur

\begin{tabular}{cccc} 
No. & Kelas Umur & Jumlah & Persentase (\%) \\
\hline 1. & $20-30$ & 10 & 10 \\
2. & $31-40$ & 1 & 27.14 \\
3. & $41-50$ & 2 & 30 \\
4. & $51-60$ & 1 & 20 \\
5. & $61-70$ & 6 & 8.5 \\
\multicolumn{2}{c}{ Total } & 70 & 100 \\
\hline
\end{tabular}

Pada Tabel 2 terlihat bahwa responden dengan umur 31-50 tahun lebih banyak ditemukan di lapangan yaitu sebesar $57.14 \%$. Hal ini berhubungan dengan aktivitas mereka yang kesehariannya dihabiskan paling banyak di laut sebagai nelayan dan mudah ditemukan. Mereka berinteraksi secara langsung dan biasanya lebih memahami mengenai ekosistem dan dampak dari keberadaan hutan mangrove.

Responden dengan usia produktif merupakan responden yang telah berumah tangga dan sangat aktif secara langsung dalam bekerja di wilayah desa tersebut. Pembuatan kelas umur termuda yaitu 21 tahun dan tertua 70 tahun dimaksudkan bahwa responden dengan kelas umur tersebut lebih tepat memungkinkan untuk mengkomunikasikan perspektifnya.

\section{Lama Menetap}

Lamanya seseorang pada wilayah tertentu baik yang tinggal/berdomisili sementara atau menetap, dan pendatang sangat mempengaruhi pengenalannya terhadap kondisi lingkungan yang ditempatinya. Terkait dengan kearifan lokal atau sosial budaya daerah setempat yang menjadi tempat tinggalnya. Interaksi baik langsung maupun tidak langsung terhadap lingkungan dari segi intensitas serta frekuensi akan dipengaruhi oleh lama tidaknya seseorang berada di suatu daerah. Berikut disajikan distribusi responden beradasarkan lama menetap pada Tabel 3.

Tabel 3. Distribusi responden berdasar lama menetap

\begin{tabular}{cccc}
\hline No. & Lama Menetap & Jumlah & Persentase (\%) \\
\hline 1. & $10-20$ & 13 & 8.57 \\
2. & $21-30$ & 17 & 24.28 \\
3. & $31-40$ & 16 & 22.85 \\
4. & $41-50$ & 12 & 17.1 \\
5. & $51-60$ & 10 & 14.28 \\
6. & $61-70$ & 2 & 2.85 \\
& Total & 70 & 100 \\
\hline
\end{tabular}

Menurut Tabel 3 jumlah responden yang menetap pada Desa Jaring Halus memiliki persentase tertinggi pada kategori kedua yaitu di kisaran umur 21-30 tahun (24.28\%). Mereka biasanya adalah putra daerah asli yang sejak lahir telah tinggal di wilayah tersebut dan ada juga sebagian sebagai pendatang dari daerah luar Jaring Halus kemudian menetap di Desa Jaring Halus karena berkeluarga dengan warga desa tersebut Dari hasil wawancara yang dilakukan responden pada kategori kedua sebagai persentase tertinggi (24.28\%) ditemukan warga yang kurang mengetahui mengenai perubahan-perubahan lingkungan yang menjadi tempat barunya. Sementara responden yang sejak lahir berada di lokasi tersebut maupun responden yang telah menetap di atas 31 hingga 70 tahun ternyata lebih mengerti mengenai dinamika perubahan lingkungan yang terjadi.

\section{Pendidikan}

Pendidikan responden diklasifikasi- kan ke dalam lima kategori menurut pendidikan formal yang pernah mereka jalani. Kategori tersebut dimulai dari kategori tidak sekolah, kategori SD, kategori SLTP, kategori SLTA hingga kategori perguruan tinggi (PT).

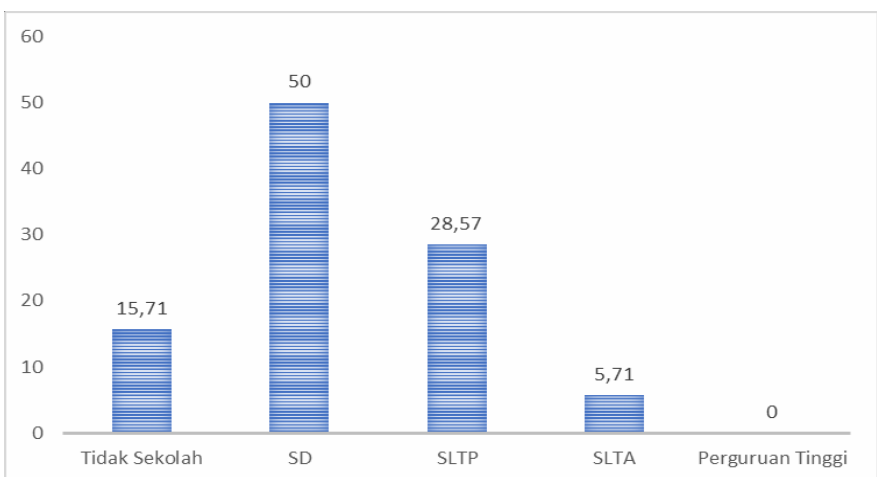

Gambar 1. Persentase (\%) tingkat pendidikan responden masyarakat desa jaring halus

Pada Gambar 1 dapat diketahui bahwa tingkat pendidikan yang dimiliki oleh masyarakat Desa Jaring Halus secara umum tergolong sangat rendah. Rata-rata responden yang diwawancarai memiliki latar pendidikan paling banyak hanya sampai pada tingkat sekolah dasar (SD) yaitu sebesar $50 \%$, SLTP yaitu sebesar $28.57 \%$, SLTA sebesar $5.71 \%$, dan yang tidak sekolah sebesar $15.71 \%$. Berbagai faktor penyebab latar belakang rendahnya pendidikan mereka adalah disebabkan oleh rendahnya taraf hidup/perekonomian masyarakat, serta 
rendahnya kesadaran akan pentingnya pendidikan. Kebutuhan sandang pangan inilah yang menuntut banyak warga Desa Jaring Halus memutuskan untuk bekerja mencari nafkah dan menghentikan pendidikannya. Pola pikir yang terdapat pada masyarakat Desa Jaring Halus lebih mementingkan pemenuhan kebutuhan daripada pendidikan.

Kondisi pendidikan semacam ini mempengaruhi persepsi masyarakat terhadap alam sekitarnya. Misalnya, tingkat kesadaran lingkungan akan sampah yang rendah. Seperti diketahui bahwa di Desa Jaring Halus banyak didapati limbah seperti lumbung sampah yang tidak terurai seperti plastik, yang kemudian apabila terjadi pasang, sampah tersebut masuk kedalam ekosistem hutan. Tidak jarang ditemukan sampah anorganik terdapat di areal hutan, hal ini dapat menyebabkan terganggunya organisme laut yang berkembang biak di areal sekitar hutan mangrove seperti ikan- ikan kecil, udang, dan lain-lain.

\section{Pekerjaan}

Masyarakat Desa Jaring Halus yang merupakan masyarakat pesisir dengan latar belakang perekonomiannya tidak dapat dipisahkan dari produksi perikanan di daerah tersebut. Secara umum sistem perekonomian masyarakat ditopang oleh hasil-hasil laut terutama hasil perikanan.

Tabel 4. Jenis pekerjaan responden

\begin{tabular}{|c|c|c|c|c|c|}
\hline \multirow{3}{*}{ No } & \multirow{3}{*}{ Jenis } & \multicolumn{4}{|c|}{ Pekerjaan } \\
\hline & & \multicolumn{2}{|c|}{ Tetap } & \multicolumn{2}{|c|}{ Tidak Tetap } \\
\hline & & Jumlah & $\%$ & Jumlah & $\%$ \\
\hline 1. & Nelayan & 65 & 92 & 14 & 100 \\
\hline 2. & Guru & 1 & 1.42 & - & - \\
\hline 3. & Pedagang & 2 & 2.85 & - & - \\
\hline 4. & Wiraswasta & 1 & 1.42 & - & - \\
\hline 5. & Dukun Beranak & 1 & 1.42 & - & - \\
\hline & Total & 70 & 100 & 14 & 100 \\
\hline
\end{tabular}

Berdasarkan Tabel 4 diketahui bahwa pekerjaan pokok yang paling banyak adalah sebagai nelayan. Profesi nelayan di Desa Jaring Halus sudah menjadi mata pencahrian prioritas, sebab sistem yang dibangun di desa tersebut adalah sistem tauke. Jadi para nelayan yang tidak memiliki modal untuk melaut seperti perahu, jaring, dan pelampung untuk jaring disediakan oleh tauke. Jadi bahan hasil tangkapan di laut di setorkan ke tauke dengan pemotongan pembayaran alat-alat melaut tersebut. Untuk penyetoran bahan hasil tangkapan sendiri harus tetap pada tauke yang memberi modal sampai batas pembayaran modal awal lunas. Untuk pekerjaan sampingan biasanya dimiliki oleh kaum perempuan/istri dimana pada dasarnya berprofesi utama sebagai ibu rumah tangga. Dalam mengisi waktu senggang, umumnya kaum ibu-ibu membuat ikan asin, olahan terasi, dan lain-lain.

\section{Tingkat Pendapatan}

Tingkat pendapatan masyarakat Desa Jaring Halus secara langsung maupun tidak langsung sangat dipengaruhi oleh jumlah atau banyaknya tangkapan hasil laut khususnya hasil ikan. Dari hasil wawancara dengan responden, diketahui bahwa sejumlah pendapatan perbulan sulit untuk dirata-ratakan, karena jumlah hari kerja perbulan juga sangat dipengaruhi oleh banyak faktor terutama faktor peralatan yang digunakan yang sering mengalami kerusakan. Selain itu faktor iklim (angin) juga faktor musim yang sangat dipertimbangkan untuk melaksanakan penangkapan ikan di laut. Apabila sedang musim pasang mati dan angin kencang, maka para nelayan tidak bisa ketengah laut untuk mencari ikan. Berikut disajikan distribusi responden menurut tingkat pendapatan pada Tabel 5.
Tabel 5. Distribusi tingkat pendapatan responden

\begin{tabular}{cccc}
\hline No. & Pendapatan (Rp) & Jumlah & Persentase \\
\hline 1. & $500.000-1.000 .000$ & 14 & 20 \\
2. & $1.000 .001-2.000 .000$ & 31 & 44.28 \\
3. & $2.000 .001-3.000 .000$ & 18 & 25.71 \\
4. & $3.000 .001-4.000 .000$ & 2 & 2.85 \\
5. & $\geq 4.000 .001$ & 5 & 7.14 \\
\multicolumn{2}{l}{ Jumlah } & 70 & 100 \\
\hline
\end{tabular}

Berdasarkan Tabel 5 diketahui bahwa tingkat pendapatan masyarakat secara umum pada lokasi penelitian adalah tergolong sangat rendah bahkan tidak menentu tiap bulannya yaitu sebesar Rp. 500.000 1.000 .000 sebesar $20 \%$ dan pendapatan sebesar Rp. $1.000 .001-2.000 .000$ sebesar $44.28 \%$ dengan kata lain bahwa terdapat $64.28 \%$ responden yang memiliki pendapatan di bawah atau sama dengan Rp. 2.000.000. Kondisi jumlah pendapatan tersebut dikategorikan sangat rendah sesuai dengan Indikator keluarga sejahtera berdasarkan Badan Pusat Statistik tahun 2005 yang menyebutkan apabila pendapatan masyarakat < Rp. 5.000 .000 di golongkan pada kesejahteraan rendah, namun jika di tambah dengan konsumsi pengeluaran sedang dengan skor 2, keadaan tempat tinggal yang semi permanen dengan skor 2, fasilitas tempat tinggal yang cukup dengan skor 2, kesehatan anggota keluarga yang cukup dengan skor 2, kemudahan mendapatkan pelayanan kesehatan, memasukan anak ke jenjang pendidikan, dan kemudahan mendapatkan fasilitas transportasi yang cukup masing-masing dengan skor 2 dan total seluruhnya 16 maka dapat di golongkan pada kesejahteraan sedang. Terdapat hanya 7 orang yang memiliki pendapatan antara 3 juta sampai lebih dari 4 juta rupiah oleh responden dengan profesi sebagai wiraswasta yang berkaitan dengan ikan yang biasa dikenal sebagai tauke ikan. 
Sebagaimana pada Tabel 4 diketahui bahwa jenis pekerjaan responden terbanyak adalah sebagai buruh nelayan. Tingkat pendapatan masyarakat tersebut sangat berkaitan erat dengan profesi atau jenis pekerjaan yang dimiliki oleh responden pada daerah penelitian. Sebagaimana disebutkan oleh Martono (2011) bahwa profesi nelayan sering menjadi satusatunya pilihan masyarakat pesisir dengan masalah kemiskinannya yang klasik. Berdasarkan hasil wawancara hasil tangkapan para nelayan sangat bergantung pada faktor kondisi cuaca seperti badai dan angin yang terlalu kencang di laut. Pada lima tahun sebelumnya pendapatan mereka dalam melaut sangatlah rendah namun semenjak digalakannya penanaman serta penjagaan kawasan sekitarnya, hasil tangkapan terlihat cukup meningkat seiring dilestarikannya kawasan hutan mangrove. Berdasarkan informasi dari responden, juga diketahui apabila para nelayan sedang tidak melaut karena cuaca buruk biasanya mereka mencari ikan-ikan kecil dan udang di sekitaran hutan mangrove guna memenuhi kebutuhan pangannya.

\section{Eksistensi Hutan Mangrove Terhadap Masyarakat}

Hasil penelitian ini diharapkan dapat menggambarkan kondisi secara umum masyarakat sekitar hutan mangrove di berbagai daerah Indonesia yang pantainya memiliki hutan mangrove serta memiliki interaksi dengan hutan mangrove. Sebagaimana disebutkan oleh Alongi (2002) bahwa hutan mangrove dimanfaatkan secara besar-besaran dengan cara tradisional maupun komersial di seluruh dunia. Pada Tabel 6 di bawah ini akan disajikan pemahaman masyarakat terhadap hutan mangrove di desa Jaring Halus.

Tabel 6. Pemahaman/pengetahuan masyarakat terhadap hutan mangrove

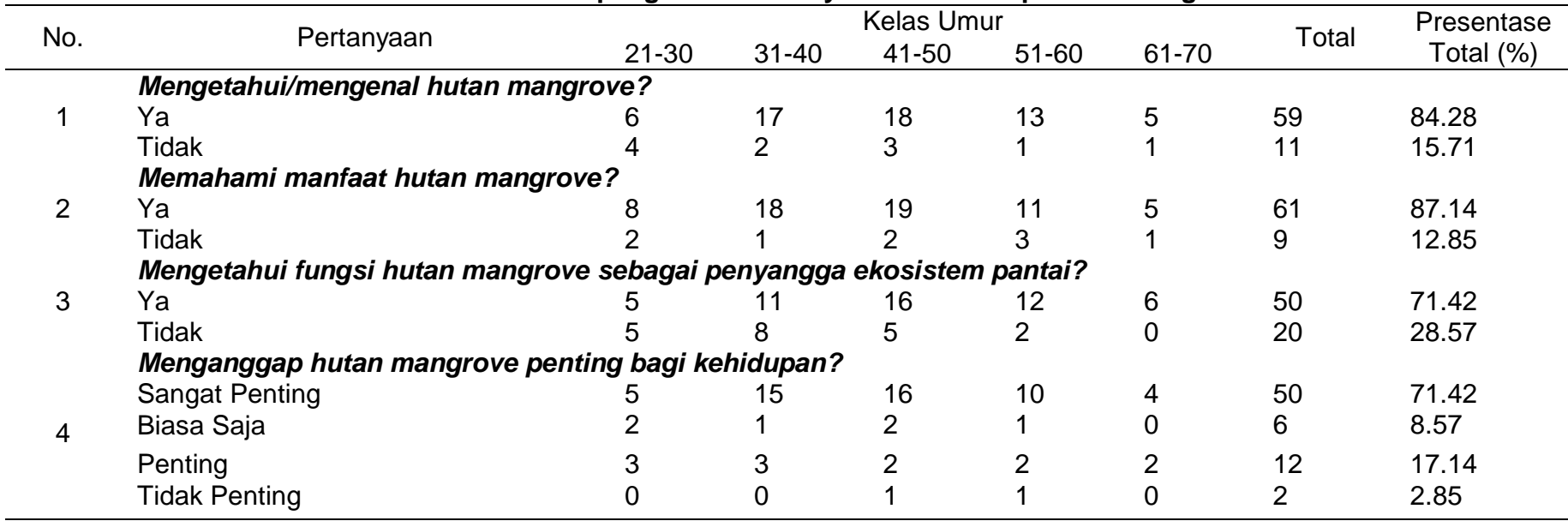

Berdasarkan Tabel 6 ditunjukkan bahwa persentase pengetahuan masyarakat terhadap hutan mangrove tergolong sangat baik. Terdapat $84.28 \%$ responden yang mengenal hutan mangrove secara sederhana, dan sebanyak $87.14 \%$ memahami akan manfaatnya, bahkan $71.42 \%$ masyarakat juga memahami jika ekosistem hutan mangrove tersebut berfungsi sebagai penyangga ekosistem pantai. Masyarakat memahami bahwa mangrove mampu menahan atau meredam angin kencang yang berasal dari laut, memecah ombak yang menuju darat serta menjaga terjadinya abrasi di wilayah bibir pantai secara alami. Hasil penelitian ini memperlihatkan bahwa $71.42 \%$ masyarakat Desa Jaring Halus merasakan hutan mangrove bermanfaat sebagai sumber penghidupan mereka. Selain itu sebanyak $8.57 \%$ responden menyatakan bahwa ekosistem hutan mangrove biasa saja bagi kehidupannya, dan $2.85 \%$ menyatakan bahwa ekosistem hutan mangrove sama sekali tidak penting bagi kehidupan mereka dikarenakan beberapa responden bermata pencaharian bukan nelayan sehingga tidak ada interaksi secara langsung dengan ekosistem hutan mangrove.

Masyarakat setempat yang paling banyak mengenal dan mengetahui manfaat ekosistem mangrove merupakan mereka yang tinggal di sekitar kawasan hutan mangrove dalam kurun waktu yang cukup lama baik yang merupakan masyarakat asli desa tersebut maupun pendatang serta penduduk yang lebih banyak berinteraksi dengan hutan mangrove seperti para nelayan, penambak ikan/udang, pencari kayu bakar di kawasan hutan. Sementara warga yang tidak memiliki hubungan secara langsung dengan hutan mangrove tersebut cenderung tidak mengenal hutan mangrove. Eksploitasi sumberdaya alam untuk kebutuhan rumah tangga tidak diawasi secara resmi sehingga masyarakat diperbolehkan untuk menebang pohon sesuai kebutuhannya (Zorini $d k k, 2004)$.

Selain itu terkait pemanfaatan sumberdaya alam untuk kebutuhan sehari-hari dalam budaya masyarakat Desa Jaring Halus sudah ada peraturan tidak tertulis yang mengatur bahwasannya siapa pun yang mengambil kayu dari hutan harus menanam kembali satu bibit sebagai gantinya. Hal ini tetap membutuhkan pengawasan yang baik dari pemerintah maupun dari masyarakat. Desa Jaring Halus sudah memiliki suatu organisasi yaitu Ikatan Petani dan Nelayan Jaring Halus (IPANJAR) yang bergerak dalam bidang perlindungan dan pengawasan ekosistem hutan mangrove secara faktual di lapangan. Berikut disajikan informasi terkait perhatian masyarakat terhadap perubahan kondisi mangrove pada Tabel 7 . 
Adnin Musadri Asbi dan Rahman Abdel Rouf, Pengaruh Eksistensi Hutan Mangrove terhadap Aspek Sosial, Ekonomi dan Kearifan Lokal Masyarakat Pesisir di Desa Jaring Halus, Kecamatan Secanggang, Kabupaten Langkat

Tabel 7. Perhatian masyarakat terhadap perubahan kondisi hutan mangrove

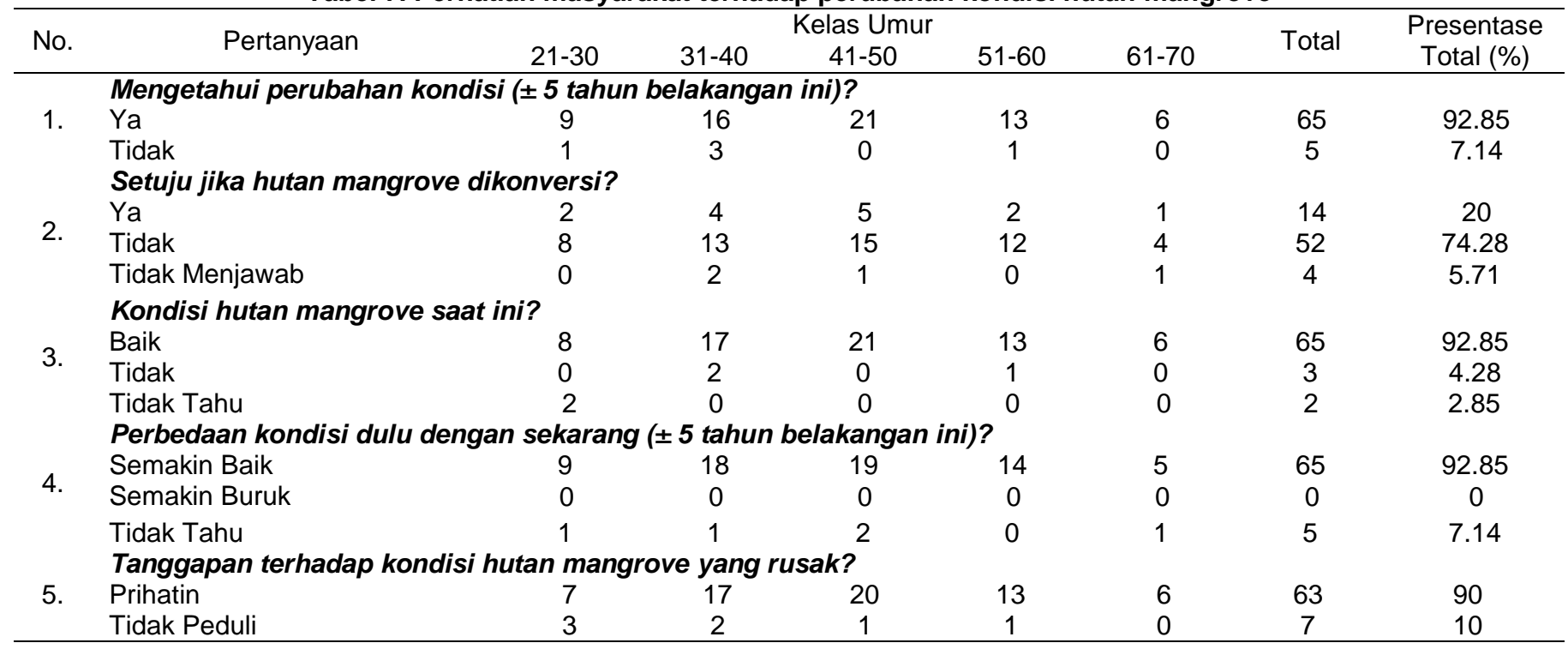

Tabel 7 menunjukkan bahwa perhatian masyarakat terhadap kondisi hutan mangrove yang berada di sekitar mereka menjadi indikasi kondisi hutan yang baik dan tidak rusak. Terdapat $92.85 \%$ responden masyarakat Desa Jaring Halus merasakan ada perubahan kondisi mangrove selama lima tahun belakangan ini, seperti penambahan jumlah/luasan akibat adanya kegiatan penanaman dan pemeliharaan mangrove sehingga kawasan di bibir pantai semakin meluas.

Sebanyak $74.28 \%$ responden tidak setuju jika hutan mangrove di sekitar mereka dikonversi untuk kegunaan lain seperti perkebunan sawit, industri, perumahan dan lain-lain karena dikhawatirkan dapat mengganggu penghasilan tangkapan ikan mereka di laut akibat hilangnya peran mangrove dalam perkembangbiakan biota laut seperti ikan-ikan kecil, udang, kepiting, dan sebagainya. Di sisi lain, terdapat $20 \%$ responden yang setuju jika hutan mangrove di konversi ke fungsi lainnya dengan alasan konversi lahan seperti sawit, tambak, dan lain sebagainya dapat mendatangkan keuntungan ekonomi yang lebih tinggi dan dapat mengangkat taraf hidup mereka. Terdapat pula sejumlah kecil (5.71\%) responden yang ragu-ragu atau tidak menjawab karena minimnya pemahaman responden mengenai dampak panjang dari konversi hutan mangrove.

Menurut responden, berdasarkan apa yang mereka lihat dan amati selama lima tahun terakhir di lingkungan sekitar, sebanyak $92.85 \%$ responden melihat kondisi semakin baik dari lima tahun sebelumnya. Selain itu ada $7.14 \%$ dari total responden masyarakat yang tidak mengetahui perubahan kondisi lingkungan sekitar dikarenakan jenis pekerjaan yang tidak berinteraksi langsung dengan mangrove. Terdapat sejumlah $10 \%$ responden yang tidak perduli terhadap perubahan ekosistem hutan mangrove dengan alasan bahwa mangrove tidak berdampak secara langsung pada perekonomian mereka. Sebanyak 90\% responden merasa perihatin terhadap kondisi vegetasi mangrove yang telah rusak akibat konversi lahan dan pemanfaatan hutan mangrove yang terjadi.

Masalah lingkungan yang paling dikhawatirkan responden apabila terjadi pengrusakan lahan hutan mangrove oleh pihak-pihak yang tidak bertanggung jawab adalah dampak buruk terhadap potensi bencana di daerah mereka seperti tsunami, intrusi air laut, naiknya permukaan air laut menuju daratan, erosi/longsornya pantai oleh ombak serta mati atau tumbangnya pohon-pohon mangrove yang tumbuh paling dekat dengan laut akibat terpaan angin dan ombak yang dirasakan semakin kuat. Keprihatinan masyarakat yang tinggi terhadap kondisi kerusakan ekosistem hutan mangrove di sekitar mereka tanpa adanya sebuah aksi bukan sebuah solusi untuk mengatasi masalah lingkungan yang terjadi saat ini. Hutan mangrove yang sudah ada sekarang haruslah tetap dijaga kelestariannya. Berikut disajikan perspektif masyarakat terhadap kegiatan restorasi pada Tabel 8.

Tabel 8. Perspektif masyarakat terhadap kegiatan restorasi

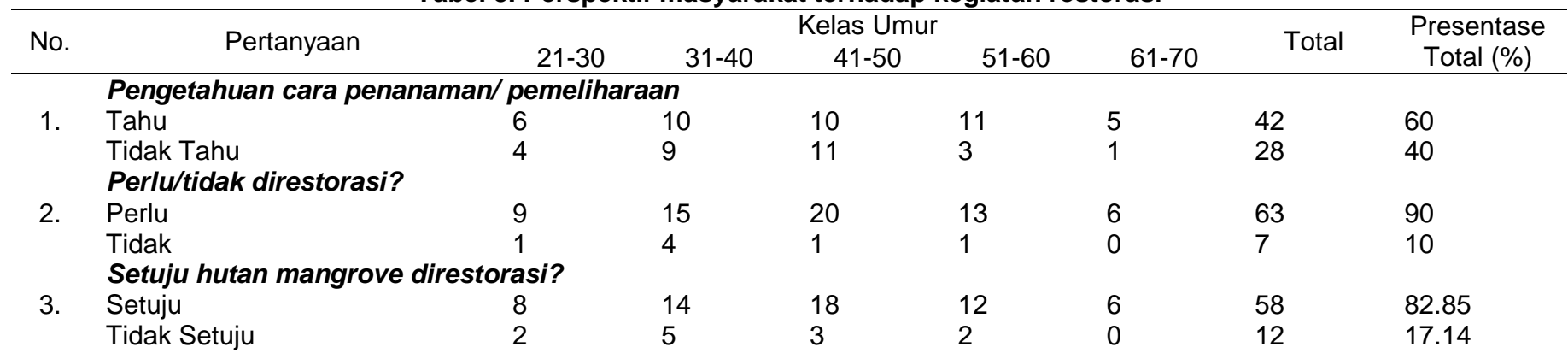


Adnin Musadri Asbi dan Rahman Abdel Rouf, Pengaruh Eksistensi Hutan Mangrove terhadap Aspek Sosial, Ekonomi dan Kearifan Lokal Masyarakat Pesisir di Desa Jaring Halus, Kecamatan Secanggang, Kabupaten Langkat

\begin{tabular}{|c|c|c|c|c|c|c|c|c|}
\hline & \multicolumn{8}{|c|}{ Yang harus terlibat dalam kegiatan restorasi? } \\
\hline & Pemerintah saja & 2 & 4 & 3 & 1 & 1 & 11 & 15.71 \\
\hline \multirow[t]{4}{*}{4.} & Masyarakat saja & 0 & 1 & 0 & 1 & 0 & 2 & 2.85 \\
\hline & Lembaga atau Institusi saja & 1 & 0 & 0 & 0 & 0 & 1 & 1.42 \\
\hline & Semua pihak a, b dan c & 7 & 14 & 18 & 12 & 5 & 56 & 80 \\
\hline & \multicolumn{8}{|c|}{ Tanggapan terhadap mahasiswa/ instansi yang melakukan restorasi? } \\
\hline \multirow[t]{3}{*}{5.} & Sangat Mendukung & 10 & 18 & 18 & 13 & 6 & 65 & 92.85 \\
\hline & Tidak Mendukung & 0 & 1 & 3 & 1 & 0 & 5 & 7.14 \\
\hline & \multicolumn{8}{|c|}{ Respon terhadap kegiatan restorasi? } \\
\hline \multirow[t]{2}{*}{6.} & Mau Terlibat & 9 & 17 & 19 & 13 & 5 & 63 & 90 \\
\hline & Tidak Mau Terlibat & 1 & 2 & 2 & 1 & 1 & 7 & 10 \\
\hline
\end{tabular}

Pada Tabel 8 diatas terlihat bahwa pengetahuan masyarakat dalam menanam / memelihara mangrove tergolong cukup baik (60\%). Jumlah responden yang berpendapat bahwa hutan mangrove yang rusak perlu direstorasi juga sangat tinggi yaitu sebesar 90 dan sangat setuju (82.85\% responden) untuk dilaksanakannya restorasi. Sebanyak $80 \%$ responden memilih opsi keterlibatan semua pihak (pemerintah, masyarakat, lembaga/institusi) dalam melaksanakan program restorasi mangrove daripada hanya dilakukan oleh satu pihak baik itu masyarakat saja $(2.85 \%$ responden), lembaga/instansi saja (1.42\% responden), atau pemerintah saja ( $15.71 \%$ responden).

Pengetahuan sederhana masyarakat secara umum dalam melakukan penanaman mangrove yaitu dengan mengambil langsung anakan (propagule) yang tumbuh di alam dan menanam kembali di tempat yang mereka kehendaki, walaupun secara fakta di lapangan metode ini diketahui kurang efektif dan berhasil diterapkan akibat besarnya potensi rusak/matinya anakan muda tersebut dalam proses pertumbuhannya akibat arus dan ombak, serta ketidaksesuaian area dengan jenis yang ditanam.

Primavera dan Esteban (2008) menyebutkan bahwa faktor rendahnya tingkat ketahanan dapat terjadi disebabkan oleh faktor spesies yang tidak sesuai dan pemilihan lokasi. Tujuan dan alasan masyarakat melakukan penanaman mangrove biasanya memiliki berbagai latar belakang atau motivasi sebagaimana hasil penelitian Walters (2004), bahwa motivasi tertinggi penanaman mangrove oleh masyarakat Filipina adalah sebagai perlindungan badai dan sebagai penyedia bahan bangunan.

Pembuatan pembibitan untuk menumbuhkan dan menanam benih mangrove bukan suatu hal yang baru bagi masyarakat Desa Jaring Halus. Mereka sudah melakukannya sejak dahulu, dan mereka belajar secara otodidak berdasarkan pengalaman. Responden memiliki tanggapan yang sangat mendukung $(92.85 \%)$ terhadap mahasiswa/lembaga intansi yang melakukan kegiatan restorasi di wilayah mereka. Hanya sedikit saja (7.14\%) yang tidak mendukung dengan alasan tidak perlu dilakukan restorasi. Sebanyak $90 \%$ responden bersedia mendukung /berpartisipasi dan menyatakan mau terlibat dalam kegiatan restorasi jika dilokasi mereka dilaksanakan kegiatan restorasi. Sementara 10\% tidak mau terlibat dengan alasan tidak memiliki waktu dan takut berinteraksi dengan orang lain atau tergantung pada upah yang diberi saat penanaman per bibitnya.
Perlunya dilakukan usaha untuk dapat memperbaiki taraf hidup masyarakat Desa Jaring Halus dengan memanfaatkan sumberdaya hutan mangrove secara lestari. Membuat pembibitan permanen yang dikelola oleh pemerintah desa yang dikerjakan oleh masyarakat dan dipasarkan keluar daerah sesuai peruntukannya guna meningkatkan penghasilan rumah tangga. Hal ini diperkuat dengan rencana pemerintah desa yang sudah disetujui oleh Pihak Kabupaten Langkat untuk menjadikan Desa Jaring Halus sebagai KEE (Kawasan Ekosistem Ekowisata).

\section{Kearifan Lokal Masyarakat Desa Jaring Halus}

Berdasarkan hasil wawancara diketahui bahwa secara umum responden/masyarakat sudah memahami arti pentingnya ekosistem mangrove bagi kelangsungan hidup masyarakat baik secara fisik, ekologi, maupun ekonomi. Secara fisik dan ekologi, hutan mangrove berfungsi sebagai benteng yang dapat melindungi permukiman dari badai, ombak, dan abrasi. Secara ekonomi, hutan mangrove berfungsi sebagai tempat mencari ikan dan tempat pemijahan berberapa jenis ikan, kepiting bakau, udang, dan berbagai jenis kerang. Pengetahuan dan pemahaman masyarakat terhadap pentingnya hutan mangrove tersebut disebabkan karena tingkat ketergantungan masyarakat terhadap hutan mangrove cukup tinggi terkait dengan mata pencaharian sebagai nelayan (fungsi ekonomi) dan fungsi hutan mangrove untuk melindungi pemukiman (fungsi fisik dan ekologi). Dalam kehidupan sehari-hari, masyarakat Desa Jaring Halus biasa memanfaatkan kayu-kayu dari hutan mangrove desa untuk berbagai keperluan seperti galah ambai, tiang tambatan perahu, kayu bakar untuk pesta perkawinan dan kematian, serta kayu untuk pembuatan balai dan pentas jika ada pesta perkawinan.

Meski demikian, masyarakat menyadari bahwa pemanfaatan hutan mangrove desa tersebut harus diimbangi dengan upaya pelestarian. Terkait dengan hal ini, Desa Jaring Halus sudah mempunyai peraturan tidak tertulis yang sudah melekat di masyarakat yang mengatur pemanfaatan dan pengelolaan hutan mangrove desa. Berdasarkan hasil wawancara dengan pawang (tokoh masyarakat terkait dengan adat istiadat) dan responden diketahui beberapa aturan dalam pemanfaatan/pengelolaan yang ada di Desa Jaring Halus diantaranya:

- Batang dan ranting kayu yang sudah mati boleh dimanfaatkan untuk kayu bakar atau keperluan lainnya; 
- Pengambilan/penebangan kayu untuk pembuatan balai, pentas, dan kayu bakar jika ada pesta perkawinan atau kematian harus mendapat ijin dari pemerintah desa dan pawang desa;

- Penebangan/pengambilan kayu mangrove untuk tujuan komersial /dijual tidak diperbolehkan dan akan dikenakan sanksi/denda mulai peringatan keras sampai denda yang nilainya mencapai jutaan rupiah jika melakukannya. Menurut responden, sampai saat ini belum pernah ada masyarakat yang terkena denda berupa uang tersebut.

Adanya peraturan tidak tertulis (telah ada sejak desa ini berdiri sekitar tahun 1917- an) yang masih ditaati oleh masyarakat tersebut membuat semua responden optimis terhadap kelestarian hutan mangrove desanya. Meski demikian, ancaman terhadap kelestarian hutan mangrove Desa Jaring Halus tetap ada berupa adanya kegiatan pencurian kayu mangrove yang dilakukan oleh masyarakat di luar desa yang memanfaatkan kayu mangrove untuk membuat arang. Berdasarkan pengalaman responden, pencuri yang berasal dari luar desa yang tertangkap basah diberi peringatan untuk tidak mengulangi perbuatannya dengan cara menyita perahu serta hasil kayu tebangannya.

Upaya pengamanan hutan mangrove desa tidak dilakukan oleh petugas khusus tapi dilakukan secara sukarela jika masyarakat mengambil ikan dari sekitar hutan mangrove desa. Dari hasil wawancara juga diketahui bahwa terdapat kesadaran dari masyarakat untuk menanam kembali hutan mangrove desa yang mengalami kerusakan dengan mengambil buah/biji mangrove dan menyemaikannya secara swadaya kemudian ditanam lagi di hutan mangrove desa. Selain itu, masyarakat Desa Jaring Halus juga mempunyai kearifan lokal yang lain yang berkaitan tidak langsung dengan kelestarian hutan mangrove di sekitar desa, yaitu tradisi jamu laut yang pada awalnya dahulu dilaksanakan setiap setahun sekali kemudian 3 tahun sekali dan kemudian disepakati menjadi 5 tahun sekali. Upacara jamu laut ini adalah seperti upacara adat yang mereka yakini sebagai hari dimana arwah para leluhur penunggu Desa Jaring Halus datang dan memasuki desa. Pada saat hari yang sudah ditentukan, semua warga berkumpul di pantai untuk melakukan zikir/doa di tepi pantai dan makan-makan bersama. Setelah itu, semua warga harus pergi ke darat terutama anak-anak dan kaum wanita untuk beberapa waktu.

Berdasarkan potensi kearifan budaya lokal masyarakat Desa Jaring Halus diperoleh bahwa sebagian besar kearifan lokal mengarah kepada keyakinan terhadap suatu religi. Sebagai suatu sistem religi, menurut Koentjaraningrat (1993), kepercayaan masyarakat terdiri dari tiga unsur/komponen, yaitu (1) Emosi, yang menyebabkan manusia bersikap religius. Emosi adalah suatu getaran jiwa yang dapat menggerak jiwa manusia baik secara individu maupun kelompok (2) Sistem keyakinan yang mengandung segala keyakinan manusia tentang supranatural, wujud alam gaib, nilai dan norma dari kepercayaan (3) Sistem ritus dan upacara yang merupakan usaha manusia untuk mencari hubungan dengan dewa-dewa, supranatural atau makhluk-makhluk yang mendiami alam gaib.

Ritus (upacara suci) ini menyangkut hal ibadat yang dilakukan dan ini dapat diamati, termasuk mantra, ucapan-ucapan tertentu, nyanyian, doa, pemujaan, kurban dan sebagainya. Fungsi upacara ini adalah selain untuk memperkuat keyakinan, juga memperkuat sistem dan nilai sosial yang ada dalam masyarakat. (4) Umat dan kesatuan sosial yang menganut sistem keyakinan tersebut, seperti suku bangsa dan lain-lain.

Makna lain yang dapat disimak dari kearifan lokal/tradisional yang dimiliki oleh masyarakat pesisir di Desa Jaring Halus adalah selalu terciptanya suasana kekerabatan dan kegotong-royongan diantara masyarakat nelayan, hubungan sosial yang harmonis, saling membantu. Oleh karena itu, perilaku mencuri, bersaing yang tidak sehat, saling merusak perlengkapan penangkapan nelayan tidak pernah terjadi di Desa Jaring Halus karena telah terbiasa tidak bersifat serakah dalam memanfaatkan sumberdaya. Semacam ada pesan moral bagi mereka bahwa mereka hanya boleh menangkap untuk kepentingan hidup mereka (konsumsi), atau dijual untuk keperluan yang lain. Penangkapan dalam jumlah yang banyak dan besarbesaran tidak pernah terjadi. Mereka mempersepsikan kearifan lokal sebagai sesuatu yang dapat menata kehidupan baik antar mereka sebagai komunitas sosial maupun dengan alam sebagai komunitas ekologis. Masyarakat Desa Jaring Halus juga menyadari bahwa eksistensi kehidupan mereka tidak terlepas dari eksistensi kehidupan makhluk lain dalam bumi satu sama lain. Oleh karena itu bagi nelayan lokal, ketaatan dan kepatuhan terhadap aturan adat, kearifan dan tradisi yang ada sangatlah dijunjung tinggi. Di lain pihak, masyarakat di desa ini juga mempunyai respon yang cukup pesimistis terhadap implementasi dan penegakan hukum formal yang berlaku saat ini.

\section{SIMPULAN}

Dilihat dari hasil dan pembahasan diatas didapatkan kesimpulan bahwa keberadaan hutan mangrove berpengaruh langsung terhadap pertumbuhan ekonomi masyarakat Desa Jaring Halus yaitu sebesar $92.85 \%$ dari total responden masyarakat, selain itu mereka juga merasakan dampak positif dalam kehidupan sosial mereka dari terpeliharanya hutan mangrove di Desa Jaring Halus. Masyarakat Desa Jaring Halus memiliki kearifan lokal yang tidak tertulis dalam mengelola dan menjaga kelestarian hutan mangrove untuk mempertahankan keutuhan sosial dan ekonomi yang berekesinambungan.

Dalam upaya melestarikan hutan mangrove, perlu dibuat pembibitan mangrove secara permanen yang dikelola oleh pemerintah desa yang dikerjakan oleh masyarakat dan dipasarkan keluar daerah sesuai peruntukannya untuk meningkatkan penghasilan rumah tangga dengan memanfaatkan rencana pencetusan Desa Jaring Halus sebagai KEE (Kawasan Ekosistem Ekowisata). Untuk mendukung hal tersebut perlu lebih melibatkan peran masyarakat lokal untuk meningkatkan respon yang sangat baik terhadap kegiatan pemeliharaan hutan mangrove untuk keberlanjutan ekosistem mangrove yang sudah terjaga. Serta 
diperlukan penelitian- penelitian selanjutnya terkait masalah sosial ekonomi, budaya dan kearifan lokal di wilayah lain sebagai refrensi keragaman budaya Indonesia dalam menjaga hutan.

\section{DAFTAR PUSTAKA}

Alho, C. J. R., M. Schneider, and L.A. Vasconcellos. (2002). Degree of threat to the biological diversity in the ilha grande state park (RJ) and guidelines for conservation. Brazilian Journal of Biology 62(3):375-385.

Alongi, D. M. (2002). Present state and future of the world's mangrove forests. Environmental Conservation. 29 (3):331-349.

Anwar, C. dan E. Subiandono. (1996). Pedoman Teknis Penanaman Mangrove. Info Hutan No 65, Puslit Hutan dan Konservasi Alam. Bogor.

Arikunto, S. (2006). Prosedur Penelitian: Suatu Pendekatan Praktek. Rineka Cipta. Jakarta

Babo, N. R dan J.W. Froelich. (1998). Community-Based Mangrove Rehabilitation: A Lesson Learned from East Sinjai, South Sulawesi, Indonesia.

Badan Pusat Statistik. (2005). Direktorat Jenderal Pemberdayaan Masyarakat Desa. Departemen Dalam Negeri.

Balai Desa Jaring Halus. (2014). Profil Desa Jaring Halus. Kabupaten Langkat.

BB KSDA Sumut, USAID-ESP, YARL, dan IPANJAR. (2006). Perjanjian Kerjasama Pengelolaan SM LTL secara Kolaboratif. Medan.

Bengen, D. (1998). Ekosistem dan Sumberdaya Hutan Mangrove. Makalah dalam Pelatihan Singkat Perlindungan Lingkungan Mangrove dan Tambak, Bogor, 19-22 Oktober 1998. Bogor.

Mangrove. Mangrove Action Project dan Yayasan Akar Rumput Laut Indonesia. Yogyakarta.

Effendi, I. (2004). Pengantar Akuakultur. Penebar Swadaya. Jakarta.

Food and Agriculture Organization (FAO). (1992). Management and Utilation of Mangrove in Asia and The Pasific. FAO Environmental Paper III. FAO. Rome.

Khoja, T.M. (2000). Impact of human activity on biotic communities in the al qatif oasis, Saudi Arabia. Pakistan Journal of Biological Sciences 3(2):209-214

Khazali, M. (2001). Potensi, Peran dan Pengelolaan Mangrove. Seminar dan Lokakarya Nasional Pengelolaan dan Pemanfaatan Pulau Nusakambangan Sebagai Sisa-Sisa Hutan Hujan Daratan Rendah Berupa Ekosistem Kepulauan di Era Otonomi Daerah, Yogyakarta, 12-13 Mei 2001. Yogyakarta.

Koentjaraningrat. (1993). Pengantar Antropologi: Pokok-pokok Etnografi II, Rineka Cipta: Jakarta. Kusmana, C. (1999). Pedoman Pembuatan Persemaian Jenis-Jenis Pohon Mangrove. Jurusan Manajemen Hutan, Fakultas Kehutanan IPB. Bogor.
Martono, M. (2011). Sosiologi Perubahan Sosial. Perspektif Klasik, Modern, Posmoderen dan Poskolonial. PT. Raja Grafindo Persada. Jakarta.

Noor, Y. R., M. Khazali, dan I.N.N. Suryadiputra. (1999). Panduan Pengenalan Mangrove di Indonesia. WI-IP/PKA. Bogor.

Nybakken, J. W. (1992). Biologi Laut: Suatu Pendekatan Ekologis. Diterjemahkan oleh Eidman, $\mathrm{H}$.

M., Koesoebiono, Bengen, D. G., Hutomo M., dan Subarjo, S. PT. Gramedia Pustaka. Jakarta. Primavera, J.H. dan Esteban, J.M.A. (2008). A review of mangrove rehabilitation in the Philippines: successes, failures and

future prospects. Philippines. Wetlands Ecology Management. (16):345-358.

Spalding, M., M. Kainuma, L. Collins. (2010). World Atlas of Mangroves. Earthscan. London.

Vanucci, M. (2001). What is so special about mangroves?. Brazilian Journal of Biology 61(4):599-603.

Walters, B.B. (2004). Local management of mangrove forests in the Philippines: successful conservation or efficient resources exploitation. Human Ecology 32 (2) :374-379.

Zorini, L.O. Contini, C. Jiddawi, N. Ochiewo, J. Shunulaand, J. Cannicci, S. (2004).

Participatory appraisal for potential community-based mangrove management in East Africa. Wetlands Ecology and Management. (12):87-102. 